\title{
The Story of the Old Rectory in Žilina
}

\author{
Miloš Dudáš
}

Associate Professor, Dipl. Ing. Miloš Dudáš, PhD

Regional Monuments Board of Žilina

Mariánske nám. 19

01001 Žilina

Slovakia

email:milos.dudas@pamiatky.gov.sk

\&

University of Žilina in Žilina

Faculty of Humanities

Univerzitná 8215/1

01026 Žilina

Slovakia

e-mail: milos.dudas@fhv.uniza.sk

Muzeológia a kulturne dedićstvo, 2021, 9:1:97-118

DOI: $10.46284 / \mathrm{mkd} .2021 .9 .1 .6$

The Story of the Old Rectory in Zilina

The fate of the so-called Old Rectory in Žilina, situated next to the monumental Church of the Holy Trinity, was emotionally charged, controversial and, in the end, very sad. The Rectory's architecture and construction reflected both the needs of its various owners, and many of the dramatic events that had affected the city throughout its history. Despite repeated damage by fire, the faith community always found the strength and energy to restore the building and bring it back to life. Up until 1989, the Rectory was an integral part of the community's spiritual life, and even after then, its upper storey continued to serve as the Church's pastoral centre and a meeting place for Christian youth activities, while the ground floor housed the city's Tourist Information Board and a popular restaurant. The Rectory was declared a national cultural monument in 2008, just as a developer was taking an interest in the site on which it stood. At this point, the local Church authorities decided it was not worthy of salvation and swiftly lodged an appeal against the decision to protect it, downplaying the building's historical and architectural value, suggesting that since its original Late Medieval/ Early Modern features had been lost to fire 1678, the current building, reconstructed in 1777, was of no significant value. While a decision on the appeal was still pending, the Rectory was demolished, in the middle of Saturday night, July 12, 2008. The ground on which it stood was completely excavated within a week, allowing no possibility of recovery archaeological research. Eventually, a shopping centre was built over the place it once stood. This article discusses the controversial processes that led to the building's abrupt demolition, and explores the failure to bring charges against those responsible for its destruction, which took place contrary to the Monuments Act.

Keywords: Rectory, national cultural monument, declaration, church, demolition

In September 1987, the historic core of Žilina was declared an urban monument reservation. ${ }^{1}$ Despite the fact that its historical architecture and period details do not quite make it the equal of such cities as Levoča, Bardejov, Košice, Kremnica or Banská Štiavnica, its monumental-historical value is undeniable. It displays a clearly legible and almost intactly preserved historical urbanism, which, together with a special legal system, was brought to Žilina at the turn of the thirteenth and fourteenth centuries by German settlers, most notably the Saxons. On a slight hill, in the immediate vicinity of the already standing church, they established a market

${ }^{1}$ The Government of the Slovak Socialist Republic, under Resolution No. 194/1987 of 11 September 1987, declared the cities of Trenčín, Trnava and Žilina to be urban monument reservations. 
square with a rectangular network of streets, which were placed within the oval floor plan of an older settlement. ${ }^{2}$ Žilina never became a Free Royal City; it was only an agricultural town led by a hereditary mayor. Nevertheless, by the end of the Middle Ages, it was one of the largest and most important cities in Slovakia, and its legal sphere of influence extended over a wide area. Dozens of villages were governed by the law of Žilina, and the burghers of Žilina were hereditary mayors in many settlements. ${ }^{3}$

One of the likely reasons Zilina never gained the privilege of a Free Royal City was the absence of brick fortifications. The people of Žilina did not build such defenses, even though King Sigismund of Luxembourg (1368-1437) ordered them to do so by his decree of 15 April 1405, which stated:

that the city of Zilina are to be enriched with the usual walls and other suitable or necessary fortifications in the city and on its perimeter. Elected burghers are to professionally measure the perimeter of the city.... We also want, and by this regulation we establish, that the burghers, guests and inhabitants of the city are to contribute personally and materially to the construction of the intended moat and other fortifications at the appropriate time, namely to build walls, moats and fortifications. We also establish that townspeople and inhabitants of Žilina, as well as inhabitants and the whole villages of Strečno, Starý hrad and Hričov, are to provide the necessary carriages at their own expense, together and continuously helping each other. ${ }^{4}$

The people of Žilina probably started the construction, but they were not able to finish the work on the masonry walls. The costs were too high and Hussites who were staying in the town and its surroundings in the 1430s did not bring peace or provide resources for this work. This was perhaps why Matej Korvín (1443-1490) forgave taxes in Žilina for three years in 1474, but even that did not help. ${ }^{5}$ The city never got its brick walls. In the end, it was protected only by earthen ramparts, wooden palisades, moats, two main gates - the Upper and the Lower Gates - and a smaller pedestrian gate.

At present, the medieval plan of the city is clearly legible in its urban structure and some streets bear names directly derived from its original form (for example, the streets $\mathrm{Na}$ bráne, Dolný val, Horný val, and $\mathrm{Na}$ priekope). Today, the position of moats and ramparts is indicated only by strips and green areas, which, however, are constantly shrinking under the pressure of the construction of new parking spaces. The extent of medieval Žilina, that is, the territory inside its "fortification", is basically reproduced in the boundaries today's urban monument reservation.

Until recently, residents and visitors who came to the city centre on foot from the railway station could perceive a silhouette and other characteristics of the city that had remained al-

\footnotetext{
${ }^{2}$ The almost regular square floor plan of the market square covers an area of 1 hectare, where each side measures approximately 100 metres. Individual sides of the square were originally divided into ten long, narrow plots, on which burghers' houses were gradually built. The first/ground floor was mostly wooden. Later, after a fire in 1521, it already became storeyed and was constructed in brick. On the ground floor of the house there are open arcades (so-called laubne) which create a unique atmosphere and a special genius loci.

${ }^{3}$ MORAVČÍK, Jozef. Prečo sa Žilina nestala slobodným královským mestom? In: My, Žilinské noviny, 21. November 2008, p. 34.

${ }^{4}$ DVOŘ́́K, Pavel (ed.). Pramene k dejinám Slovenska a Slovákov V. Prý cisár na uborskom tróne. Slovensko v čase polstoročnej vlády uhorského, českého, lombardského a nemeckého krála a rímskèho cisára Žigmunda Luxemburského, syna Karola IV. In: Bratislava: Literary Information Centre, 2001, p. 136-138.

${ }^{5}$ Principles of monument care for Žilina Municipal Monument Reservation. Slovak Institute of Monument Care and Nature Protection Bratislava, 1988, T 109, p. 15-16.
} 
most intact since the Middle Ages. This is where the most impressive view of the historic part of the city opened up for people. The dominant Parish Church of the Holy Trinity and Burian's Tower, which stood adjacent to it, were lined on one side by the younger building of the Municipal Theatre and on the other side by the two-storey building of the former Rectory. Today, we can no longer see this typical Žilina panorama. The historic Rectory was replaced by the materially oversized and architecturally disruptive new shopping centre, known as Mirage. It is an appropriate name for the building, which, from its position on the edge of the Žilina Municipal Monument Reservation area, acts literally as an illusion, a Fata Morgana, a vision or a delusion ... but since 2010, it has been a reality.

The historic Žilina Rectory stood only a few metres from the Parish Church, on a busy main pedestrian route, on the corner of the streets Dolný val (Dolný Rampart) and Farské schody (Parish Stairs). It is via these streets, and further along Farská Street, that people most often approach the historic square. The Parish decided on the further development of the burgher houses on Dolný val street situated on a terrain break above the original Váh River and its local tributary. ${ }^{6}$ During the 1960 s and 70 s, houses with a medieval core on one side of the street were renovated and the original urbanism of this part of the city was partially disturbed. For many years, the vacated space was used only as a temporary parking lot, but it was intended as a reservation area for future development. This was not realized until the beginning of this century. ${ }^{7}$

The Farské schody themselves were built on the site of the Rectory garden only in the $1920 \mathrm{~s}^{8}{ }^{8}$ Under public pressure and after the replacement of the affected land, the Church agreed to build them so that the main square could be connected to the street leading from the railway station. ' The station was established around the turn of the twentieth century, after the construction of the Košice-Bohumín Railway which, in the following decades, enabled the rapid economic development of the city. At the time the Farské schody were being built, the original medieval fortifications of the church, along with the ossuary building, were destroyed and the Rectory garden was completely destroyed. The Rectory thus became a solitary building, but closely related to the medieval urban structure of the historic city centre.

The first written mention of the Rectory in Žilina dates to the beginning of the fourteenth century and the first known pastor, Ján, worked here in 1357, as Žilina had the privilege of choosing its own pastor. ${ }^{10}$ Around the middle of the sixteenth century, the Rectory was taken over by the Evangelicals of the Augsburg faith (so-called Lutherans), who, together with the current Parish Church of the Holy Trinity, administered it for more than 150 years. Throughout the turbulent seventeenth century, the Church and the adjoining Rectory building, under varyingly dramatic circumstances, alternated between the hands of Roman Catholic believers and the temporary use of the Evangelicals. It was only after the defeat of the Kuruk troops in the battle of Trenčín at the end of 1708 that the Church and the Rectory unambiguously belonged to the Roman Catholic Church.

\footnotetext{
${ }^{6}$ In the past, the area was called "Pod farou", and period maps show that even in the eighteenth century there were larger bodies of water, probably ponds and later a brewery; today this area is included as part of Andrej Hlinka Square.

${ }^{7}$ In 2006, underground garages were built on this site, as the first stage of the future shopping centre.

${ }^{8}$ Farské schody, as a separate street, was created only in 1992 by its separation from Farská Street.

${ }^{9}$ The current Národná Street, which changed its name several times in the twentieth century (Lajosa Kossuth Street, T. G. Masaryk Street, Hlinkova Street and the Street of the Slovak National Uprising).

${ }^{10}$ PRIKRYL, Lubomir. Stručné dejiny farnosti Žilina. Rímskokatolícky farský úrad, Farnost’ Žilina - mesto, 2006, p. 11.
} 
We know very little about the appearance of the oldest Parish building in Žilina - only that there was a ground floor and probably a two-room stone building with a hipped roof which stood near the Parish Church. Until 1586, it bore the patronage of the Blessed Virgin Mary.

On August 30,1678, a large part of the city was destroyed by a devastating fire. It seriously damaged the houses on the square, the nearby church, and the Rectory. While the church was quickly restored by the faithful, the Rectory was not repaired, according to the current general knowledge and opinion of some Žilina residents and the Church itself. In theory, it should have completely disappeared, based on the fact that from the end of the seventeenth century, leadership of the local Roman Catholic parish was taken over by the Jesuits, who soon held the position of parish priests in Žilina. ${ }^{11}$ According to this hypothesis, they no longer needed a Rectory damaged by fire, because they resided instead in one of the burgher houses, in a nearby square. ${ }^{12}$ It was the Jesuits who were to dismantle the disturbed Rectory in 1699 and use the materials to build a new school. ${ }^{13}$ After the abolition of their order in 1773 and their subsequent departure from Žilina, the town's representatives, in 1777, built a completely new parish building, two storeys high, on the site of the original Rectory. This means that, according to this hypothesis, the original single-storey Rectory disappeared and a new one was built "on a green field" after only a hundred years or so. However, it is questionable whether the Rectory was not at least provisionally repaired and used by the Evangelicals after the fire in 1678, as they operated in the city until the beginning of the eighteenth century, including in the years 1704 to 1708, when a prominent Evangelical priest and superintendent, Daniel Krman Jr. (1663-1740), author of the well-known Baroque travelogue itinerary, preached in Žilina. ${ }^{14}$

Like the rest of the city, the newly built Rectory, along with an older and perhaps only temporarily repaired building, did not escape other dramatic events. On June 21, 1848, another large fire damaged the Rectory. The shingle roof and the entire floor were destroyed. At the same time, an extremely rare library with a chronicle was irretrievably lost. The Rectory was not restored until 1855, and that repair can be assessed as a late classical stage of the building's development. The intervention mainly concerned a dispositional change to the floor, which, however, respected the previous late Baroque arrangement. A new truss with sheet metal roofing was built and the floor and wooden beamed ceilings underwent the most radical restoration on the ground and first floors. Massive chimney bodies from the second half of the eighteenth century and the oldest vaulted room were preserved. This repair is probably related to the hastily built rear longitudinal wall, where, perhaps due to lack of funds, low-quality unfired brick was used.

Another large-scale fire engulfed the city centre in 1886, causing extensive damage, destroying almost all the roofs of the square houses, and severely damaging the Church. The Rectory did not escape its ravages. The subsequent repairs dragged on for many years and the Church

\footnotetext{
${ }^{11}$ The first known Jesuit to became a Parish Priest of Žilina was Juraj Jankovič (1638-1696), in 1688. PRIKRYL, L'ubomír. Stručné dejiny farnosti Žilina. Rímskokatolícky farský úrad, Farnost' Žilina - mesto, 2006, p. 15.

${ }^{12}$ Most probably it was one of the burgher houses, on the site of which the Jesuits built a church and a monastery in the middle of the eighteenth century (today the Church of the Conversion of St Paul).

${ }^{13}$ The Jesuits built the school on the other side of the Church of the Holy Trinity. In 1775 it was replaced by the Catholic Boys' Elementary School building and finally, during the Second World War, by the building of the socalled Representative House (today's Municipal Theatre).

${ }^{14}$ In May 1708, Daniel Krman Jr. set out from Žilina on a journey to the Swedish King Charles XII (1682-1718) to seek support from him for the High Mountain Evangelicals. Daily records and personal travel experiences, including a description of geographical, economic, political, social and societal conditions, form the content of this work. It represents one of the best travel memoirs in our older literature.
} 
community only completed its comprehensive restoration in 1913. Among other things, this is proven by the inscription under the decorative festoon of the side façade, which reads "RENOV.1913". At this time, the facades of the building acquired a historic appearance, and a partially modified relief depicting the coat-of-arms of Upper Hungary appeared above the main entrance. The building was restored as a two-storey block with a rectangular floor plan, a simple hipped roof, and sheet metal roofing. Its disposition was continuously adjusted and adapted to the contemporary requirements of the Church. The restored building still bore the basic features of the Baroque architectural style but, on closer inspection, also reflected older architectural spaces and structures. In contrast, rather more recent classicist modifications were applied to its facades in the form of simple flat lysines, profiled cornices and window linings.

After the construction of the Farské schody and the subsequent implementation of a multi-level terrace near the Church of the Holy Trinity, the immediate surroundings of the Rectory changed significantly. Not only did the Rectory garden disappear, but at the same time the level of the surrounding terrain was reduced. Thus, the Rectory found itself in one of the busiest and most attractive parts of the pedestrian zone of the city. This could also be one of the reasons why, at the turn of the 1930s, the Church decided to carry out a new construction on its site, as well as in the area of the former garden, between Dolný val and Štôlňa Streets. The disturbed construction and technical condition of the Rectory probably weighed in this decision, as a large part of its rear wall was built of unfired brick. The church was counting on its redevelopment, although a new multi-storey department store, designed in the spirit of modern interwar functionalist architecture, was to be built in the vacant space. ${ }^{15}$ The projects were prepared by the well-known architect Michal Maximilián Scheer (1902-2000), but in 1938 only a small part of the plans was implemented due to lack of funds and a low-rise development with the retail space on a plot next to the Rectory itself. During the second half of the twentieth century, only minor building alterations were made to the Rectory, which did not fundamentally devalue its urban, architectural and artistic-historical qualities (floor replacement, additional cladding of the interior walls with a new burnt brick panel, two new windows, some new partitions and installation of technical infrastructure).

In February 1989, the Slovak Institute of Monument Care and Nature Protection in Bratislava (the legal predecessor of today's Monument Board of the Slovak Republic) sent a written recommendation and a proposal to the Ministry of Culture of the Slovak Republic to declare the Žilina Rectory a cultural monument. A specific proposal with photo documentation was prepared by the Regional Institute of Monument Care and Nature Protection Banská Bystrica, Žilina Centre (the predecessor of today's Regional Monuments Board of Žilina) in 1988. The written recommendation for the declaration stated:

The building of the Roman Catholic Rectory ..., originally Baroque, structurally modified in the Classicist style, has been preserved in an authentic form and with architectural artistic details with considerable informative value. Due to its location near the former Parish Church, it also represents an urban value in the context of historical buildings. ${ }^{16}$

The Ministry of Culture rejected the proposal in question, even though, based on the same initiative regarding monuments, the functionalist Tržnica building on Horný Val Street was

\footnotetext{
${ }^{15}$ The permit for the redevelopment of the rectory was issued by the city of Žilina on December 30, 1930 under No. $27650 / 1930$.

${ }^{16}$ Letter No. 849/89 of 21 February 1989. Archive of the Monuments Board of the Slovak Republic in Bratislava, Regional Institute of State Monuments Care and Nature Protection, Žilina Centre.
} 
declared a cultural monument of Žilina. It is not impossible that this could have been due to ideological and political perspectives that were dominant at that time. The reason for the non-declaration could also be the fact that the Church no longer relied on this building for administrative purposes because, by 1984, it had already bought a family house on the nearby Street of the Republic. The Church modified this building and, at the end of 1989, established a new Parish Office on its premises. After that, the building on the street Dolný val became known as the "Old Rectory". However, it became an unnecessary burden for the owner, and before long, the Church was considering its demolition and took the first steps in this direction, applying to the relevant building authority for remediation.

At the beginning of April 1990, a meeting was held on the premises of the Department of the Chief Architect of the District of Žilina on behalf of the District National Committee, Department of Spatial Planning. The main purpose of the meeting was to re-evaluate various construction activities that might endanger the environment. As well as discussion on suggestions for the suspension or cancellation of several of the building authority's decisions, the committee also addressed the issue of cancellation of the already issued decision on the rehabilitation of the Žilina Old Rectory. The participants did not agree with the demolition of this building, and their opinion was adopted in full by the Žilina District National Committee. ${ }^{17}$

The Old Rectory was protected from demolition, but was not declared a cultural monument, despite all efforts to the contrary. The church began to rent part of its ground floor to several business entities, including the city of Žilina itself, but still used other parts of the floor for its own purposes, namely, for various religious activities.

In the 1990s, only minor building alterations were made to the Old Rectory, as it was located in the Žilina Municipal Monument Reservation area. Two new window openings were created on the northern façade, and all the façades, including the window structures and the stucco emblem of Hungary, were re-painted. ${ }^{18}$ The owner did not perform any major restoration work on the building.

In the summer of 2007, Žilina's preservationists, in accordance with the new Monuments Act, decided to prepare a proposal to declare the Old Rectory building a national cultural monument. ${ }^{19}$ They presented their intention to the deputy owner, the Vicar General of the recently established Žilina Diocese, who welcomed this effort at a personal meeting. In accordance with the existing expert-methodological guidelines, by the end of the same year they prepared a standard draft declaration which included, among other things, the characteristics of the seat; a description of the proposed case and a declaration of its status; its current use; a justification for the proposal, including relevant characteristics of the monument; and a proposal regarding future measures. The proposal included the required historical and contemporary photographic documentation. The Monument Board of the Slovak Republic in Bratislava, before sending the complete proposal to the Ministry of Culture of the Slovak Republic, asked the Žilina Regional Monuments Board to supplement it with an architectural and historical survey of the

\footnotetext{
${ }^{17}$ Minutes of the working meeting held on April 5, 1990 at the Department of the Chief Architect of the District of Žilina. Archive of the Monuments Board of the Slovak Republic in Bratislava, fund of the Regional Institute of State Monuments Care and Nature Protection, Žilina Centre.

${ }^{18}$ The works in question, which had the character of maintenance, with respect to minor monuments, were approved by the Žilina Monuments committee in June and July 1993. Archive of the Monuments Board of the Slovak Republic in Bratislava, fund Regional Institute of State Monuments Care and Nature Protection, Žilina Centre.

${ }^{19}$ Act No. 49/2002 Coll. on the protection of the monument fund, as amended (the so-called Monument Act), defines all monuments as national cultural monuments.
} 
building. ${ }^{20}$ This survey was carried out by employees of the Žilina Regional Monuments Board in January and February 2008, using non-destructive methods, as the Old Rectory was still in use during this period. The ground floor was home to a fast-food restaurant (Pancake House) and the Tourist Information Office of the city of Žilina, while first floor housed the Pastoral Centre of the Roman Catholic Church. The survey in question, as a supplement to the proposal, summarized the monumental values of the Old Rectory into three levels: urban, architectural-historical, and art-historical. After a thorough visual evaluation of the layout and structures of the building and reassessment of the known data, the Žilina preservationists questioned the common theory of the complete destruction of the original Rectory at the end of the seventeenth century and the construction of a new Rectory in the second half of the eighteenth century. Based on their knowledge of the period context of historical stylistic architecture and its construction methods, they proposed a new theory of its uninterrupted existence and gradual building modifications. The facts supporting this new theory were first expressed in a supplement to the proposal to declare the Old Rectory a national cultural monument. ${ }^{21}$

According to the preservationists' theory, the original single-storey stone Rectory was severely damaged by fire in 1678 but was never completely dismantled or destroyed. The church community repaired the building, and it again served its purpose, with only a few breaks. After the departure of the Jesuits, pastoral activity in the city was taken over by the Rectory itself. There was most likely a need to repair and enlarge the existing Rectory, and this happened in 1777. This means that the community did not build a completely new building, but only repaired, expanded and added one floor to the original Rectory. If this was case, then we should instead describe features from this era as part of the late Baroque stage of the older building's development.

We do not know the exact year or decade the original Rectory was constructed. Some architectural details suggest that it may have been as early as the sixteenth century, but it is not entirely out of the question that it could have been even earlier, perhaps even in the late Middle Ages. This hypothesis could only have been tested by means of a comprehensive study of the architectural, historical, and archaeological features of the monument. However, none of these research directions were possible to implement at the time the proposal for its declaration as a national cultural monument was being drafted. It was not even possible to carry out any depth probes on the Rectory building's premises to verify details of its architectural-historical development, such as individual construction stages. Further, from a legislative point of view, it was not possible at that time, in accordance with the Monuments Act, to demand implementation of a full-fledged research project on a monument that was not yet a national cultural monument.

The newly expressed expert opinion on the uninterrupted existence of the Rectory was based on two basic assumptions. The first assumes a certain logic in the behaviour of the faith community and the Church itself towards its property, and the second is based on knowledge of historical building structures and construction techniques. It is not logical that no separate rectory building should have stood in Žilina for a hundred years (1678-1777). After the arrival of the Jesuits, a burgher's house on a square was supposed to have served as a clergy house. But the thing to remember is that the Rectory was located right next to the Parish Church when it

\footnotetext{
${ }^{20}$ At that time, objects were declared national cultural monuments, as defined in the Monument Act, by the Ministry of Culture of the Slovak Republic. At present, the Monument Boards of the Slovak Republic in Bratislava has this responsibility.

${ }^{21}$ Archive of the Regional Monuments Board Žilina (T 335)
} 
was held by the Protestants. During the seventeenth century, this group formed the majority of the city's population. It seems highly unlikely that the Protestant community would have left a burnt ruin with the charred remains of a rectory right next to the main city church, as part of the church grounds, especially in such an attractive and religiously significant place. Rather, it seems probable that the community would have repaired the fire-damaged single-storey stone Rectory, just as they repaired many houses in the square and, in particular, the damaged church, which they gradually equipped with new furniture. Thus, the Rectory could have continued to serve its purpose, albeit in a makeshift form. In addition, it is questionable what building material the Jesuits would have actually used from the site of the burnt Rectory in 1699, when the fire had occurred more than twenty years previously. After such a long time, the material would have been very degraded and difficult to reuse for construction purposes. Rather, it seems that the Jesuits used material from other nearby buildings, perhaps from the unused farm buildings.

Another supporting argument for these conclusions stems from the type of historic building structures and materials that the recently demolished Rectory building contained. The space on the ground floor occupied, in the late twentieth century, by Pancake House was a room with a barrel vault, with characteristic opposing sections (lunettes). This type of vault was no longer built by the end of the eighteenth century: it is typical of the late Middle Ages and Early Modern periods. Elsewhere on the ground floor and first floor, a more recent wood-beamed ceiling with an upper folded flap was added.

When comparing the rubble and the remains of masonry from different parts of the Rectory just after its demolition, there was a clearly legible difference between the building materials used in the vaulted ground-floor room and the other spaces. In this room, pure stone masonry was used, in the form of relatively large and carefully worked stone blocks. Other areas of the ground and first floors were made of mixed masonry with a large proportion of bricks; a large part of the rear longitudinal wall of the first floor of the building was made of poor-quality unfired brick. This also testifies to several separate construction stages through which the Rectory acquired its final form. If the builders had (re)built the building in its entirety, as a completely new construction in 1777, they would never have used such diverse materials, but would have made it from one and the same compact material. Therefore, it is entirely reasonable to assume that the "Pancake House" room was the oldest part of the Rectory. In other words, the hypothesis is that after it was damaged by fire in 1678, it was subsequently repaired by the faith community, and was later expanded by adding one more floor in 1777 .

The fact that there was a separate rectory building in Žilina before 1777 is also supported by data from the List of Rectories of the Nitra Diocese, collected in $1754 .^{22}$ The census states that there was a part-brick and part-wooden rectory in Žilina. Apparently, after the fire, the original single-storey stone Rectory was repaired with a wooden, perhaps only temporary, extension. It is unlikely that the inventory would have mentioned other constructions, such as the building on the nearby square, where the Jesuits had just finished establishing their monastery and completed the church (today's Church of the Conversion of St Paul).

The Žilina Regional Monuments Board supplemented the original proposal to declare the Rectory a national cultural monument with all these unearthed facts, and sent this updated information to the Monuments Board of the Slovak Republic in Bratislava. Its expert-methodological commission, as an advisory body to the Director General (Commission for the

${ }^{22}$ The inventory is stored in the State Archives in Žilina, located in Bytča, Trenčín County (ecclesiastical documents), inv. no. 1645 , No. 2 , 1754 , p. 367 , fol. 55 R. 
Assessment of the Monument Fund), which collectively assesses all initiatives and proposals for declaring national cultural monuments, as well as requests for the abolition or change of monument protection, recommended declaring the Old Rectory in Žilina a national cultural monument.

A comprehensive set of documents - the proposal, the supplemental materials, and the positive opinion of the above-mentioned commission - was sent for direct processing to the Ministry of Culture of the Slovak Republic. The Ministry, by its decision No. MK-1734 / 200851 / 7206 of 20 May 2008, declared the Old Rectory a national cultural monument.

It therefore came as a big surprise that the owner - the Roman Catholic Church, Parish of Žilina city - did not agree with the declaration. On June 4, 2008, they exercised their right to appeal against the decision. This meant that the decision to declare the Žilina Old Rectory a national cultural monument did not entered into force. The Minister of Culture himself had to decide on the appeal (the so-called dissolution).

The Church summarized the main reasons for its disagreement and appeal in several points. In the announcement, it claimed that certain procedural requirements had been violated, so it could not comment on all the documents relevant to the decision. In Church's view, the public interest had not been was not clearly demonstrated in the procedure for declaring the Rectory a national cultural monument. The Church stated that as early as 1930, a sanitation permit had been issued for the construction due to its poor technical condition, and this was not only for economic reasons. It further recalled that in 1989, the Ministry of Culture had not agreed to declare the Rectory a cultural monument. Finally, it pointed out that the Ministry's decision contained inaccuracies and gross professional errors.

It was probably while the proposal to declare the Rectory a national cultural monument was being drafted that the church diametrically changed its opinion on the building's future protection. As it turns out, they had completely different plans for the building, and that, in fact, they did not expect the building to continue existing at all. It is reasonable to believe that they had, for a long time, been negotiating with an investor who was planning to build a shopping centre around the Parish Steps, a plan which would involve construction directly on the site of the historic Rectory. The Rectory was simply in the way of these plans, occupying space in one of the most attractive and valuable plots in the city centre. The Church probably no longer saw any meaning in the Rectory's existence; it held no significant value for the institution. On the contrary, the authorities saw in it only a source of material income and profit. This attitude emerges, quite clearly, in the Information Letter of the Žilina Parishes: Žilina-mesto, Vlčince, Solinky, Salesians, Hájik on June 22, 2008, from the Vicar General of the Žilina Diocese:

Therefore, we consider it reasonable and responsible to take an opportunity that does not occur so often and receive, in the exchange for other spaces, the commercial premises, from which the diocese will have some income to support work with youth, families, charitable works, for the operation and repair of churches, etc.

In order to free up space for the construction of a shopping centre, the church had to acquire some space for its administrative functions on its new premises. At first, the Church authorities considered establishing a new episcopal office in the mall, an idea which was rejected relatively quickly. They favoured the idea that it would be more appropriate to use some of the allotted the premises for pastoral activities and offer up the rest for rent. But it is questionable whether they were serious about this. It would have been very challenging, to say the least, to convince parishioners of a plan to carry out pastoral activities in the environment of a modern 
commercial centre. It seems that the exchange mentioned in the Vicar General's letter probably had a completely different meaning.

During this period, lively and often passionate debates on the historical value of the Old Rectory began to take place among the wider professional and lay public. However, some of the arguments put forth were driven by questionable motives; for example, there were those that wished to downplay the Rectory's monumental-historical value in the eyes of the city's inhabitants and, especially, the local churchgoers, and to question expert opinions about the building. The Church itself acted in this spirit: church/parish announcements and local print media began to systematically inform believers that the Old Rectory had no historical value and that its registration as a national cultural monument was professionally unfounded and, in fact, went against the church's interests. This viewpoint was supported by the widely publicized opinions of some experts contacted by the Church.

The efforts against declaring the Rectory a national cultural monument were supported by a letter to the Ministry of Culture dated June 13, 2008, from Peter Štanský, Director of the Bytča State Archives, Žilina Branch; Lubomír Viliam Prikryl, the chronicler of the Roman Catholic Church, Parish of Žilina; Jozef Moravčík, a long-term archaeologist at the Považské Museum in Žilina; and Richard Marsina, a prominent Slovak historian, at that time working at Trnava University. ${ }^{23}$ What led them to take this step is not known, and it is questionable whether every signatory knew exactly what was written in the letter itself and what statements and arguments it contained.

The letter asked for the declaration of the Rectory as a national cultural monument to be cancelled. It fundamentally questioned the validity of the proposal and its professional foundation. The vehemence with which the authors advocated against the possible protection of the Žilina Old Rectory was astonishing. The letter disputed the Ministry's decision mainly by arguing that the majority of the data presented by experts in the proposal was incorrect. In addition, it claimed that the Ministry based its decision on incorrect information provided by the preservationists, which de facto questioned the technical side of the proposal itself.

The proposal for the declaration was prepared by the Regional Monuments Board of Žilina and all relevant data were stated in it in accordance with the latest knowledge. Some inaccuracies in the decision of the Ministry probably arose from an erroneous transcript from the submitted proposal and its supplement (data on repairs and renovations of the building in 1678, 1699 and 1777). However, from a professional point of view and in terms of the ultimate goal of the proposal, this did not change the fact that the Old Rectory was a valuable building that fully met the criteria to justify its registration as a national cultural monument. The proposal set out the case for its monumental value at the architectural-historical, artistic-historical and especially the urban-historical levels, also necessarily taking into account the location of the building and the development of the immediate vicinity of the Parish Church of the Holy Trinity. In this context, the Old Rectory held a significantly role as co-creator of the distinctive silhouette of Žilina's historical core. ${ }^{24}$ At this point, it is necessary to emphasize once again the specification of monuments and the evaluation of the significance of the Rectory, as the Regional Monument Office stated in its proposal:

Together with the building of the Parish Church and the Burian Tower, [the Rectory] forms a valuable complex of historical architecture in the most exposed part of the Žilina

\footnotetext{
${ }^{23}$ The mentioned letter is a part of the subject file agenda of the Regional Monuments Board of Žilina.

${ }^{24}$ See, for example, historical photographs of the city published in the book MRVA, Marián. Žilina na starých pobladniciach. Bratislava: Dajama, 2008.
} 
Municipal Monument Reservation. The Old Rectory is situated on the break of a terrain ridge, on which the historic core of the city is located. Panoramic views of the terrain ridge are one of the most characteristic and impressive for the city. For this reason, it is necessary to preserve the historic panorama and silhouette in the characteristic viewing cones.

The appeal letter's claim that "no research has yet been done on the existing Rectory to find medieval parts" is inaccurate and misleading. In fact, a professional and appropriately qualified employee of the Regional Monuments Board of Žilina carried out a non-destructive visual survey focused on the historic building structures and details. The survey was submitted as a professional supplement to the proposal to declare the Rectory a national cultural monument. In addition to demonstrating the architectural and historical value of the building, the survey states that:

First of all, it is the original medieval mass, preserved in the "high plinths" of the foundation structures on the southeast and northeast side (which may include parts of the buried basement, which could be specified by rescue archaeological research) and a barrel vault with opposite sections in the northeast corner of the ground floor, which is the oldest part of the interior of the Rectory, dating to the time before the "rebuilding" of theRectory in 1777 .

Another statement in the appeal letter claimed that "the parish building from 1777 has no historical significance for the city, no significant events, important for the history of the city, took place here."

This was incomprehensible and unbelievable as it rests on some highly subjective assertions as to what objects and what periods are important to our history, cultural heritage, and the very genius loci of a particular place. The Rectory still has unquestionable historical, urban, architectural, and cultural-social value: it is irrelevant whether the building is from the last third of the eighteenth century or it is older.

Another highly problematic argument the appeal letter made against the protection of the Rectory was that:

By rehabilitating the building, a comprehensive archaeological research could be carried out in this area as well, which could bring new knowledge about the origin of the town, the castle and the beginnings of the church history in this area. It is a realistic assumption that the foundations of the original older Rectory, renovated in 1699, would be found.

It goes without saying that the redevelopment of the building would irreversibly destroy the authentic building material of the historic construction. There is no case that can be made for carrying out research that completely destroys the present building, just to prove that there was an earlier building there before. Our primary task is to protect and enhance buildings of historical significance, not to demolish and destroy them, so that we can look for hypothetical remains of even older objects under them.

On the other hand, it would certainly not have been impossible to investigate the building's architectural and historical features, for example using non-invasive geophysical methods (for instance georadar, magnetometria) on the existing building while it was not in use. Such an approach could have been used to confirm or refute the existence of an older core. And, under certain circumstances, other archaeological techniques, such as interior probes or non-destruc- 
tive geophysical analysis) could verify the existence of older underground architectures. The appeal letter concluded that the redevelopment of the existing Rectory building will create preconditions for further research in the Rectory and its surroundings, which could bring important knowledge from the Middle Ages about the beginnings of the city and castle, which is more important than saving the building from 1777, which was of poor quality and quickly built and rebuilt several times.

The destructiveness of this attitude is striking and, from the point of view of cultural heritage protection, completely unacceptable. The Old Rectory building was in good material and technical condition, as is normal for this type of historical architecture, and did not show any visible signs of major static defects. Indeed, the Rectory was in use and its premises were rented commercially to various business entities, including the city of Žilina itself.

While the disintegration proceedings were taking place and the decision of the Minister of Culture was still pending, the historic Old Rectory in Žilina was demolished. This happened on the a Saturday night, through to the small hours of Sunday morning, on 12 to 13 July 2008. The excavator needed only a few hours. It was probably no coincidence that this happened at night and in the darkness, at a time when as few direct witnesses as possible were expected.

On Sunday morning, when worshipers walked to the adjacent Parish Church, they were greeted with an unpleasant surprise. On the place where, only a few hours before, the historic Żilina Rectory had stood was a large pile of building rubble. A few days later there was only a deep pit there. Thus, despite the arguments set out in the appeal letter, it was not even possible to carry out any monumental archaeological research on the site. There was nothing left of the building; it had been sacrificed to the modern construction of the shopping centre.

So, what had been going on behind the scenes that made this possible? After the Regional Monuments Board of Zilina issued a binding opinion against the application to redevelop the Rectory back in March 2008, the Church, together with the investor planning the future shopping centre, had sought a different solution to deal with the Rectory, so as not to hinder further construction activities. In close cooperation with the city, a debatable solution had been found.

On 7 July 2008, the Joint Municipal Office in Žilina, the Department of Construction and Environment, and the Department of Building Regulations issued a controversial building permit for the modification of the Old Rectory building. ${ }^{25}$ This permit spoke of the complete reconstruction of the Rectory. It set out a number of, frankly, bizarre conditions, stating the national cultural monument was to be completely dismantled, albeit without a valid decision, and then reassembled! Incidentally, the issues of the building's stone and mixed stone-brick masonry and its brick vault were discussed. After re-assembling, with a flat roof instead of the original hipped one, the building was to be incorporated into the architecture of the planned shopping centre and thus become a part of it. The permit represented a highly unusual approach to the restoration of the monument, given that the whole building was not taken into account, but only its two perimeter walls.

It is not unreasonable to suggest some of the possible underlying purposes of this solution. The wording "complete reconstruction" used in the building permit was, as later events suggest, basically a euphemism used to cover up the planned demolition. The conditions for the reconstruction contained no stipulation to preserve the authenticity and integrity of the

\footnotetext{
${ }^{25}$ Building permit No. 10657/2008 / MsÚ-OSP / Fri was issued in record time, only four days after the application was submitted. It typically takes several months for the relevant building authority to issue a building permit for similar buildings.
} 
building, either in terms of its construction materials or shape. There can be little doubt that the ultimate goal of the "complete reconstruction" of the Rectory was its destruction, and that its restoration was probably never seriously considered. This is amply proved by the secretive and abrupt manner in which it was "dismantled" overnight by an excavator. No monumental architectural-historical, art-historical, or restoration research into the historical Rectory was carried out in advance of its demolition. None of the relevant preparatory and project documentation required for this type of project, detailing the exact characteristics of the object, its valuable elements and details, was prepared in advance. The Regional Monuments Board of Žilina did not issue any decision or binding opinion on the planned modifications, even though this was a direct consequence of the wording of the Monuments Act. There was not even an opportunity to comment on the construction procedure in question, despite the fact that it was the state administration body that was concerned with this issue. The Regional Monuments Board therefore had no opportunity to raise objections and comments during the construction procedure. In these proceedings, the Construction office made full use of binding opinion on the remediation of the Rectory and adjacent buildings from March 2008. However, there were completely different construction proceedings. ${ }^{26}$

Regarding the legal problem of whether or not the Rectory was a national cultural monument at the time of its demolition, it should be recalled that the monument fund consists not only of monumental areas but also of movable and immovable national cultural monuments and objects for which the procedure for declaring national cultural monuments has been initiated. Therefore, from a legal point of view, the Old Rectory fell under the last category, that is, it was in the process of being declared a national monument, even though the decision on the declaration was not valid due to the appeal of the party to the proceedings. Pursuant to $\int$ 15 par. 4, letter a) of the Monuments Act, the owner of the object proposed for declaration as a cultural monument at the time in force was obliged to protect the object from damage, destruction, or theft from the date of the delivery the notice of commencement of proceedings and to notify the Ministry of any intended or implemented change of ownership. Despite this provision, and before the Minister of Culture was able to reach a decision, the Old Rectory was demolished, using heavy construction equipment, on the basis of a properly issued building permit. The historic Rectory in Žilina thus definitively ceased to exist and no part of it was restored or acknowledged in any way.

Based on the special commission (the so-called Appeals Commission of the Ministry of Culture of the Slovak Republic), established by the Minister of Culture, the Minister rejected the owner's appeal, and on 15 August 2008 upheld the decision to declare the Rectory a national cultural monument. Thus Old Rectory became a legally declared national cultural monument, although by then it no longer physically existed. The Monuments Board of the Slovak Republic subsequently assigned it a registration number 11566/1 in the Central List of Monuments. This was a "Solomon's solution": the monument de jure existed, but de facto it had already been destroyed.

The Monument Inspectorate of the Ministry of Culture of the Slovak Republic, in consultation with the Regional Monuments Board of Žilina, prepared two criminal notices concerning the demolition of the Rectory. Both, with the necessary attachments, were submitted on 25 July 2008 to the General Prosecutor's Office of the Slovak Republic by the Minister of Culture

${ }^{26}$ The mistake of the city of Žilina as a building authority and its violation of legal provisions in the procedure in this regard was later stated by both the District and Regional Prosecutor's Offices in Žilina (April 2009). 
himself. The first notice was against the owner for the abuse of property, according to which an important cultural interest had been damaged by applying for a building permit and, based on that permit, destroying the building, which at that time was part of the monument fund of the Slovak Republic. The second notice was against the unknown perpetrator who, without permission, excavated the area without undertaking any archaeological discovery and thus destroyed an important archaeological site (excavation of a construction pit without the providing of prior archaeological research). At the end of September 2008, the Ministry of Culture supplemented the criminal offenses in question with other (according to them) important facts which should have fulfilled the factual substance of the crime. In both notices, the Minister of Culture pointed out, among other things, the mistakes of the relevant building authority and the fact that the building permit for the building modification of the Rectory was issued in violation of the Monuments Act.

The General Prosecutor's Office forwarded the above-mentioned criminal reports to the District Prosecutor's Office in Žilina, and the investigation was first conducted by the District Department of the Žilina-West Police Force. However, the investigation went nowhere and was terminated. The Ministry of Culture had serious objections to both the procedure and the conclusion of the investigation, and turned instead to the Regional Prosecutor's Office in Žilina. They objected to the interpretation of the District Prosecutor's Office, according to which the Old Rectory did not have monument protection at the time of the demolition. According to the Ministry, this assertion was in conflict with the stipulations of the Monument Act. In the opinion of the Ministry, the interpretation of the terms "monument fund" and "cultural monument" by the District Prosecutor's Office set a legal precedent, according to which it would not be possible in future to ensure the protection of any object even after a procedure for declaring it a cultural monument had been initiated. According to the interpretation of the District Prosecutor's Office, it would be possible to destroy such objects without the criminal sanction and thus remove their protection. The investigation was finally taken over by the Regional Directorate of the Police Force, the Judicial and Criminal Police Office in Žilina. In October 2009, its investigator stated that there had been a breach of several obligations by the owner and the relevant building authority in accordance with the provisions of the Monuments and Building Act. However, according to him, there was no intentional conduct and the act in question was not defined as a criminal offense. Therefore, he halted the prosecution in February 2010. In this case, too, the Ministry of Culture objected to the cessation of criminal prosecution. At the same time, in August 2010, the Prosecutor General's Office requested a review of the regional prosecutor's procedure. They requested that criminal liability should to be inferred in the matter of the destruction of a national cultural monument. At the end of 2010, the General Prosecutor's Office announced that they upheld the opinion of the Regional Prosecutor's Office in Žilina. According to them, it was not possible to state the existing intentions of specific persons, which would be aimed at fulfilling the factual substance of the crime of abuse of property, with respect to damage and degradation of cultural heritage. On this basis, on 30 November 2010, the Ministry of Culture postponed the initiative.

The Old Rectory has not stood for more than ten years, and its pseudo-replica has not become the part of the architecture of the new shopping centre. However, it still appears in the Central List of Monuments of the Slovak Republic as a national cultural monument. This is an absurd state of affairs. The monument protection of a non-existent object lacks any logic. The Monuments Board of the Slovak Republic in Bratislava should avoid professional embarrass- 
ment and quickly abolish the monument protection of the long-defunct building.

However, the Old Rectory should not be completely lost from human memory, because the years go by fast, and people forget quickly. Despite all the dramatic events that accompanied the Rectory's immediate demise, at least a simple and tasteful memorial plaque could remind visitors to the shopping centre and all passers-by that such an object once stood here. It is hard to understand why no one, neither the church, nor the city, nor any civic initiative, such as "Zbor Žilincov", has come up with such a proposal yet.

Thus, the only material monument that today at least partially recalls the existence of the historical Rectory in Žilina is the furnace, an Art Nouveau tile kiln from the beginning of the twentieth century. However, its owner did not take care of its preservation. Literally a few hours before the insensitive demolition of the Rectory, the dismantled fired tiles were saved by the members of the Association for the Lietava Castle Preservation. They selflessly transported and stored them in a protected place. After ten years, this furnace was reconstructed and today it is fully functional and forms the part of the Lietava Castle exposition. ${ }^{27}$ In addition to the tiles of the Art Nouveau kiln, the association also saved a few fragments of an older classicist kiln with antique motifs, which also complement the castle exposition.

The police investigation into the destruction of a historic building in the very centre of the city led to the bald statement that no crime had been committed. Despite the fact that the deed happened and the Old Rectory in Žilina was demolished in a rough and insensitive manner, the culprit was not named, and no one was prosecuted. From a legal point of view, the culprit was not identified. However, the moral responsibility for the fact that Žilina lost a rare historical building - no matter how the value of its monuments was questioned - has remained. Above all, it lies on the shoulders of those who had owned and used it for many centuries and who had a moral obligation to care for it it and eventually pass it on to future generations. Why efforts to protect the building were not successful, at the very moment its importance was increasingly recognised and it became an integral part of our monument fund and cultural heritage, is incomprehensible. It is even sadder that the historic Old Rectory disappeared only a few months after Pope Benedict XVI established the Diocese of Žilina and the Parish Church of the Holy Trinity as its cathedral church. ${ }^{28}$ The Old Rectory had stood in the proximity of this church for centuries, and it was closely connected with the latter's existence. It is just another paradox that the Old Rectory disappeared in the year when Žilina commemorated, with great glory, the 800th anniversary of its first written mention. ${ }^{29}$

English translation: E. Lelakova

\footnotetext{
${ }^{27}$ The renovation of the tiled kiln was supported by the VUB Foundation. Damaged ceramic tiles were repaired, and in some places restored to their original shape, and the entire kiln was rebuilt in the traditional way. At the end of January 2018, it began to emit pleasant warmth again.

${ }^{28}$ The Diocese of Žilina (Dioccesis Zilinensis) was established on February 14, 2008 and Žilina became the seat of the Diocesan Bishop.

${ }^{29}$ The first written mention of the territory of Žilina is from 1208 in a document issued by the Nitra county. It mentions the boundaries of several properties of the Nitra diocese in the Trenčín capital, including Hričov. It was adjacent to the territory of a smaller settlement called Terra de Selinan. OKÁNIKOVÁ, Mária (ed.). 800 rokov od prvej pisomnej żmienky o žemi Žiliňany. Považské múzeum v Žiline., 2008, p. 18.
} 


\section{References}

Archival sources

Regional Monuments Board of Žilina

- Principles of monuments care for the Žilina Municipal Monuments Reserve. Slovak Institute of Monuments Care and Nature Protection in Bratislava, 1988, T 109.

- Z Žlina - historical core (block L) - monument research. Project Institute of Culture, Bratislava, 1987 - 1989.

- Proposal and supplement to the proposal for declaring a real estate a national cultural monument - Old Rectory in Žilina, Regional Monuments Board of Žilina (L. Likavčanová, M. Marček), September 2007, February 2008, T 335.

- $\quad$ File agenda: ZA-08/0322, ZA-09/0003 and ZA-10/0375.

Monuments Board of the Slovak Republic in Bratislava.

- $\quad$ Regional Institute of State Monument Care and Nature Protection Fund, Žilina Centre.

Ministry of the Interior of the Slovak Republic - State Archive in Žilina with its seat in Bytča.

- Trenčín County Fund (church documents), inv. no. 1645, no. 2, 1754, p. 367, fol. 55R.

Bibliography

DUDÁŚ, Miloš (2009). Problematika „obnovy“ objektu Starej fary v Žiline. In: Monumentorum tutela - Ocbrana pamiatok 20, Pamiatkový úrad Slovenskej republiky, Bratislava, s. 376-390.

DVOŘÁK, Pavel (ed.) (2001) Pramene ke dejinám Slovenska a Slovákov V. Prvý cisár na uborskom tróne. Slovensko v čase polstoročnej vlády uhorského, českého, lombardského a nemeckého krála a rímskeeho cisára Žigmunda Luxemburskébo, syna Karola IV. Bratislava: Literárne informačné centrum.

GROMA, Patrik - NOVÁK, Milan - PFLIEGEL, Miroslav - ŠTANSKÝ, Peter (2017). Stratená Žilina 1. Žilina: ALL MEDIA, s.r.o.

Kolektív autorov (1975). Žilina - dejiny a prítomnost’. Martin: Osveta.

KRUŠINSKÝ, Gustáv - PFLIEGEL, Miroslav (1990). Premeny Žiliny. Martin: Osveta.

LOMBARDINI, Alexander (1874). Strǔ́ný dejepis slobodnébo mesta Žilina. Turčiansky sv. Martin.

MORAVČÍK, Jozef. Prečo sa Žilina nestala slobodným královským mestom? In: My, Žilinské noviny, November 21, 2008, s. 34.

MRVA, Marián (2008). Žilina na starých pobladniciach. Bratislava: Dajama.

OKÁNIKOVÁ, Mária (ed.) (2008). 800 rokov od prvej pisomnej zmienky o zemi Žilinany. Považské múzeum v Žiline.

PRIKRYL, L'ubomír (2006). Stručné dejiny farnosti Žilina. Rímskokatolícky farský úrad, Farnost' Žilina - mesto. 


\section{Appendix}

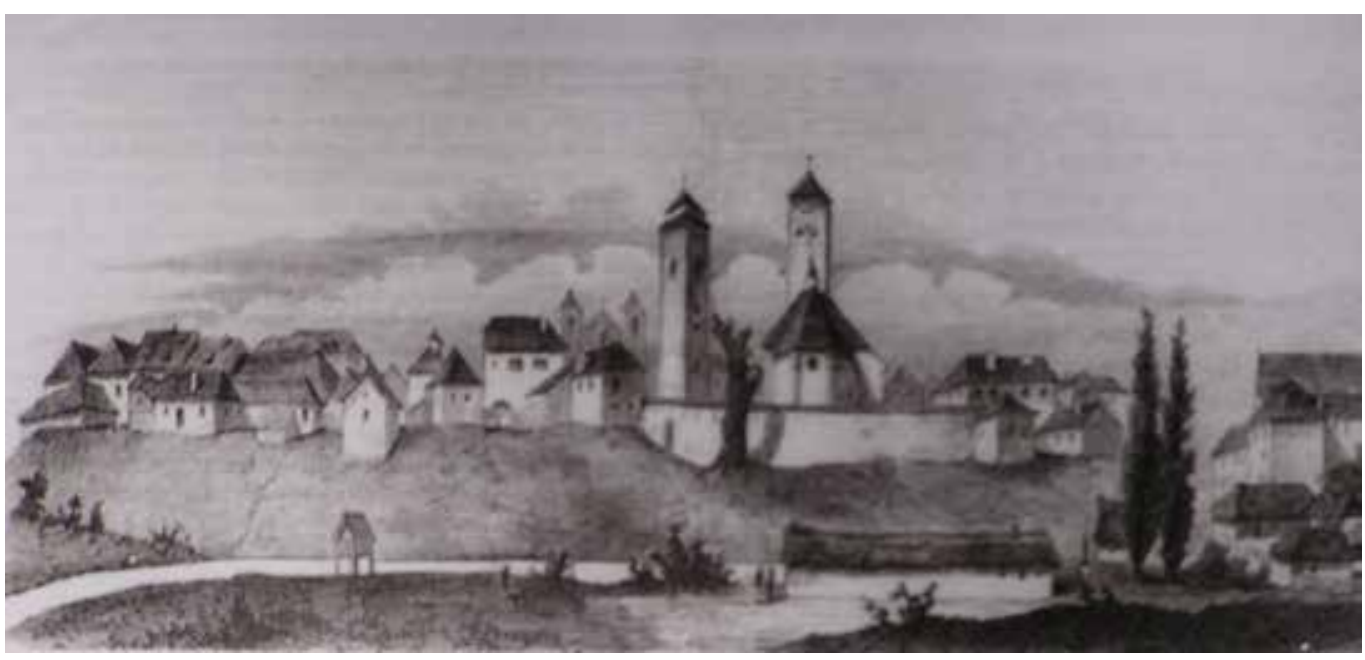

Fig. 1: The town of Žilina in the middle of the nineteenth century (Regional Monuments Board of Žilina)

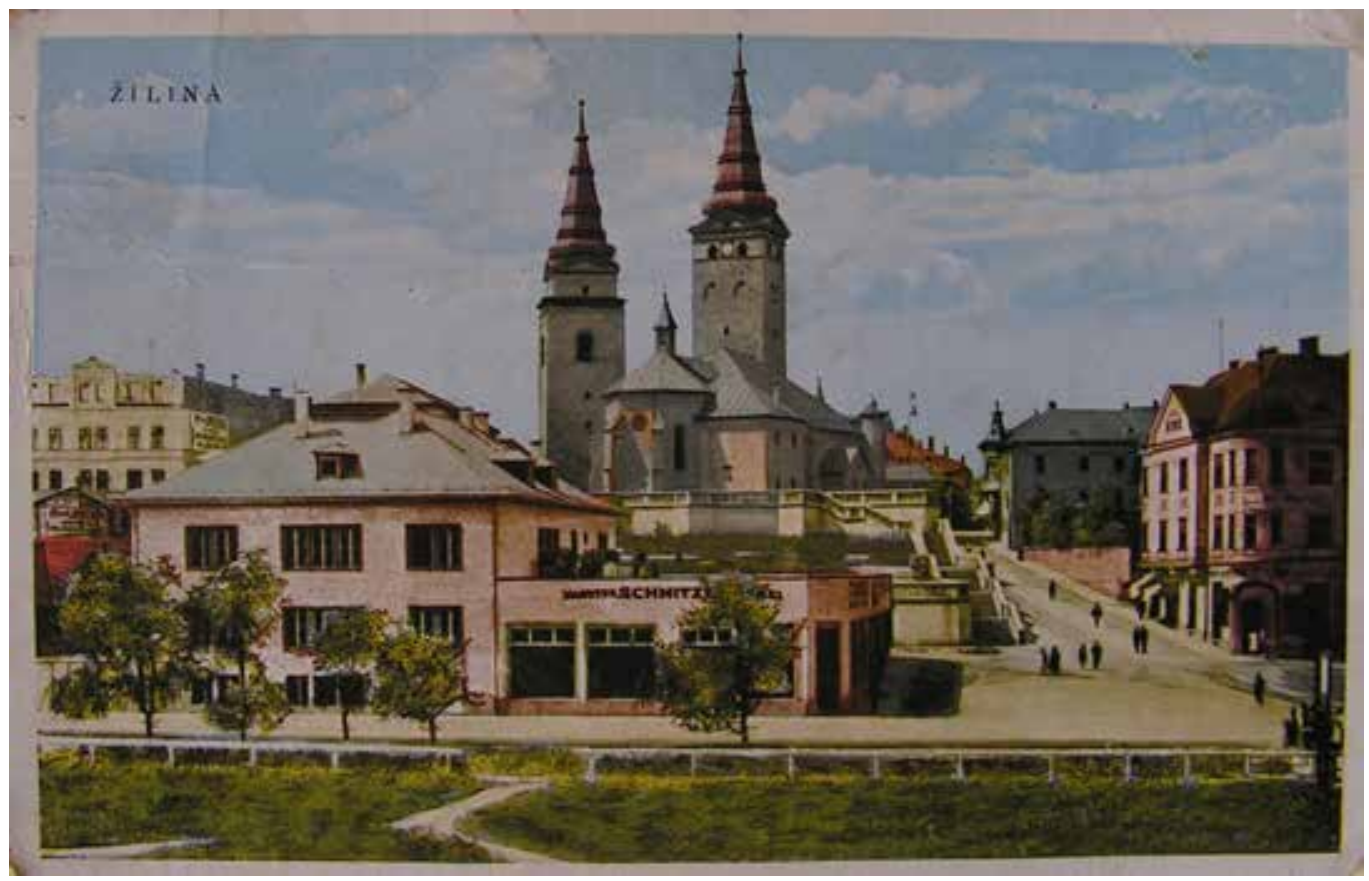

Fig. 2: The Holy Trinity Church and the Rectory at the beginning of the twentieth century (Regional Monuments Board of Zilina) 


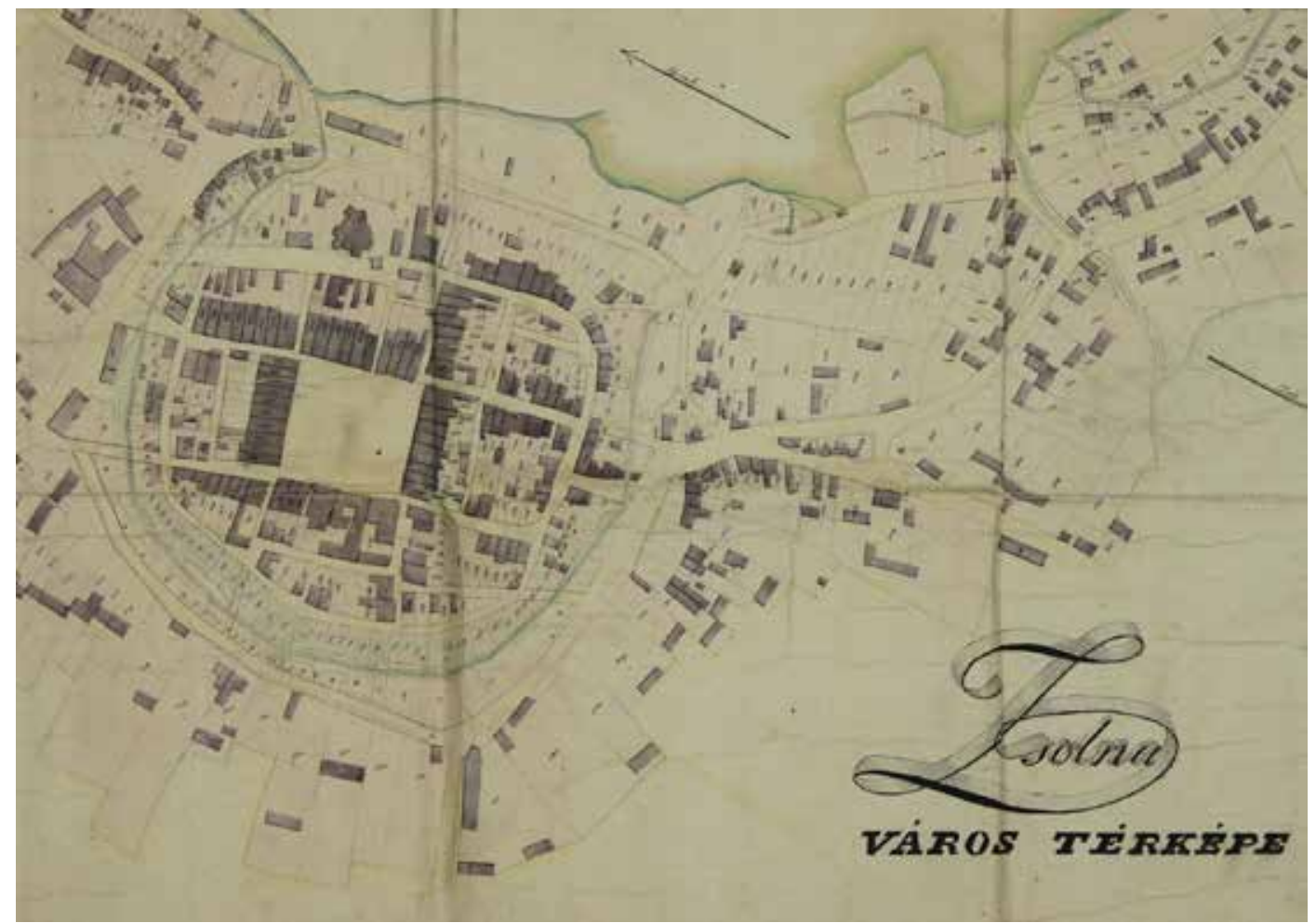

Fig. 3: The map of the town, 1848 (State Archive in Zilina with its seat in Bytra)

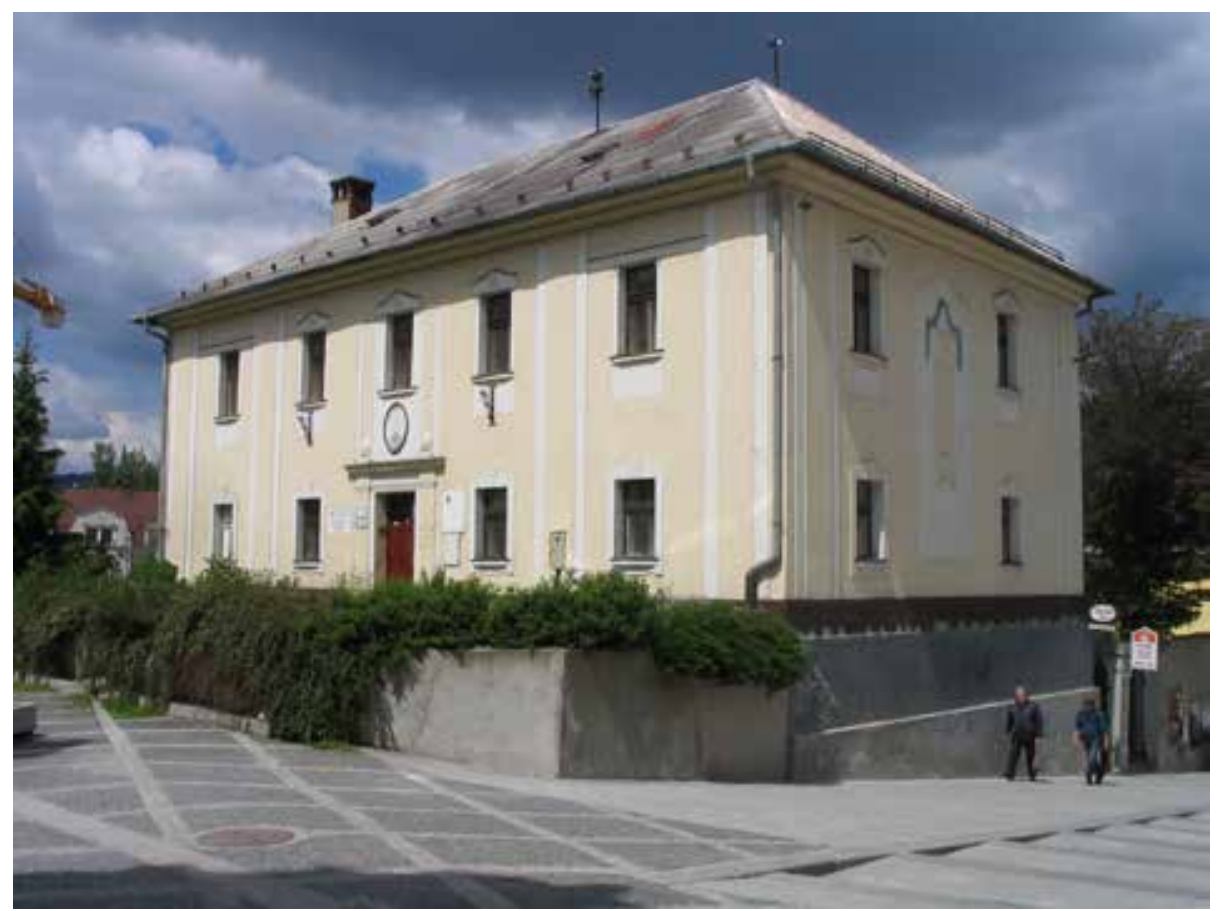

Fig. 4: The Rectory several weeks before its demolition (photo: J. Feiler, 2008) 

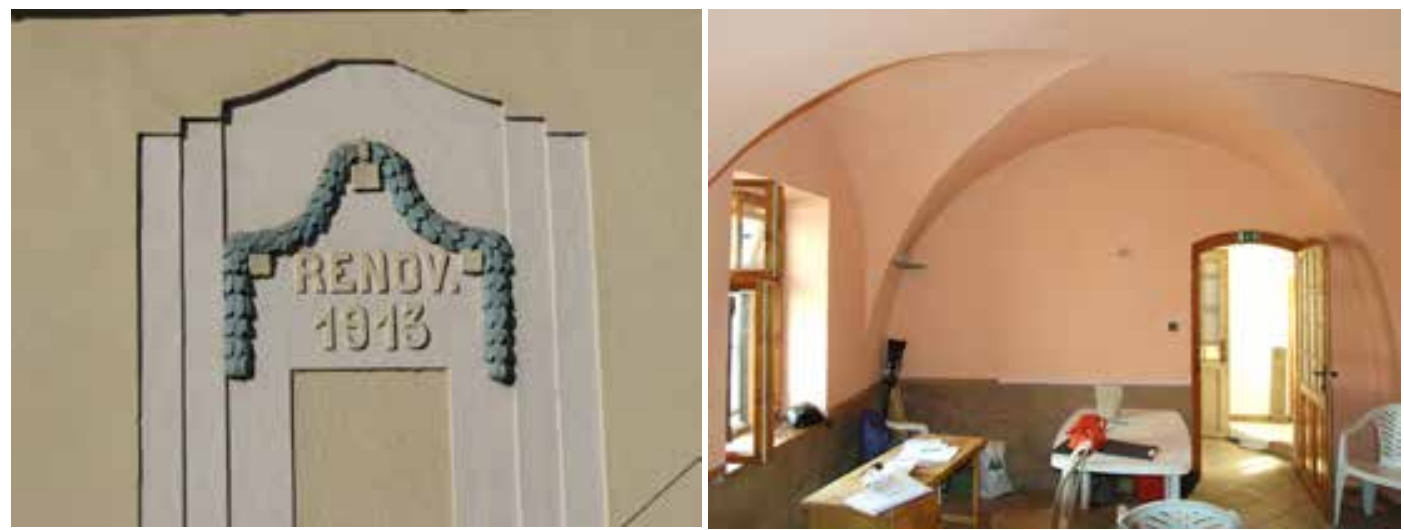

Fig. 5: Detail of the facade (photo: J. Feiler, 2008)

Fig. 6: The oldest room of the rectory, dating from the Late

Medieval or Early Modern era (photo: M. Dudás, 2008)

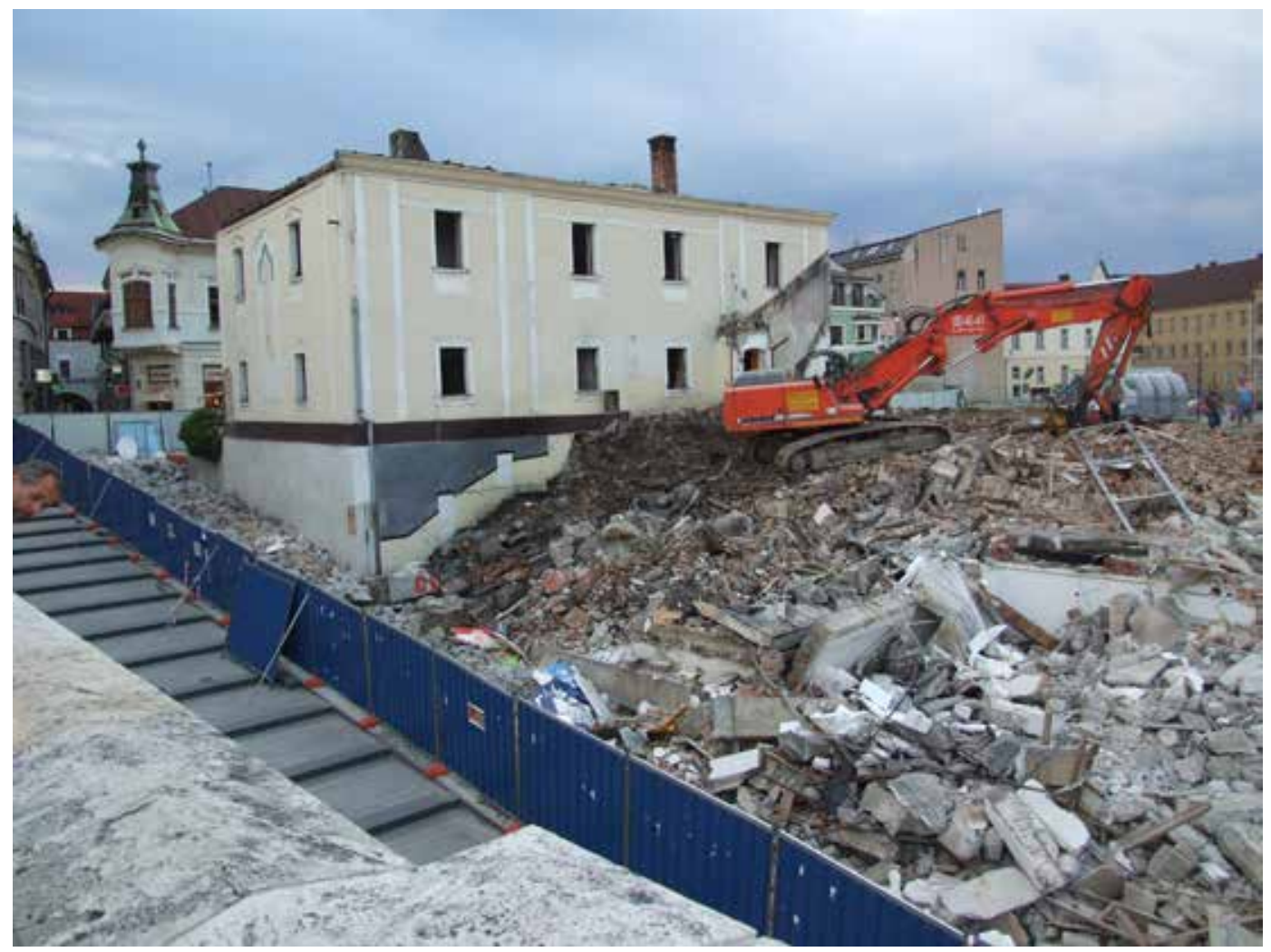

Fig. 7: The beginning of the Rectory's demolition, July, 2008 (photo: M. Dudás') 


\section{STAVEBNÝ VÝVOJ}
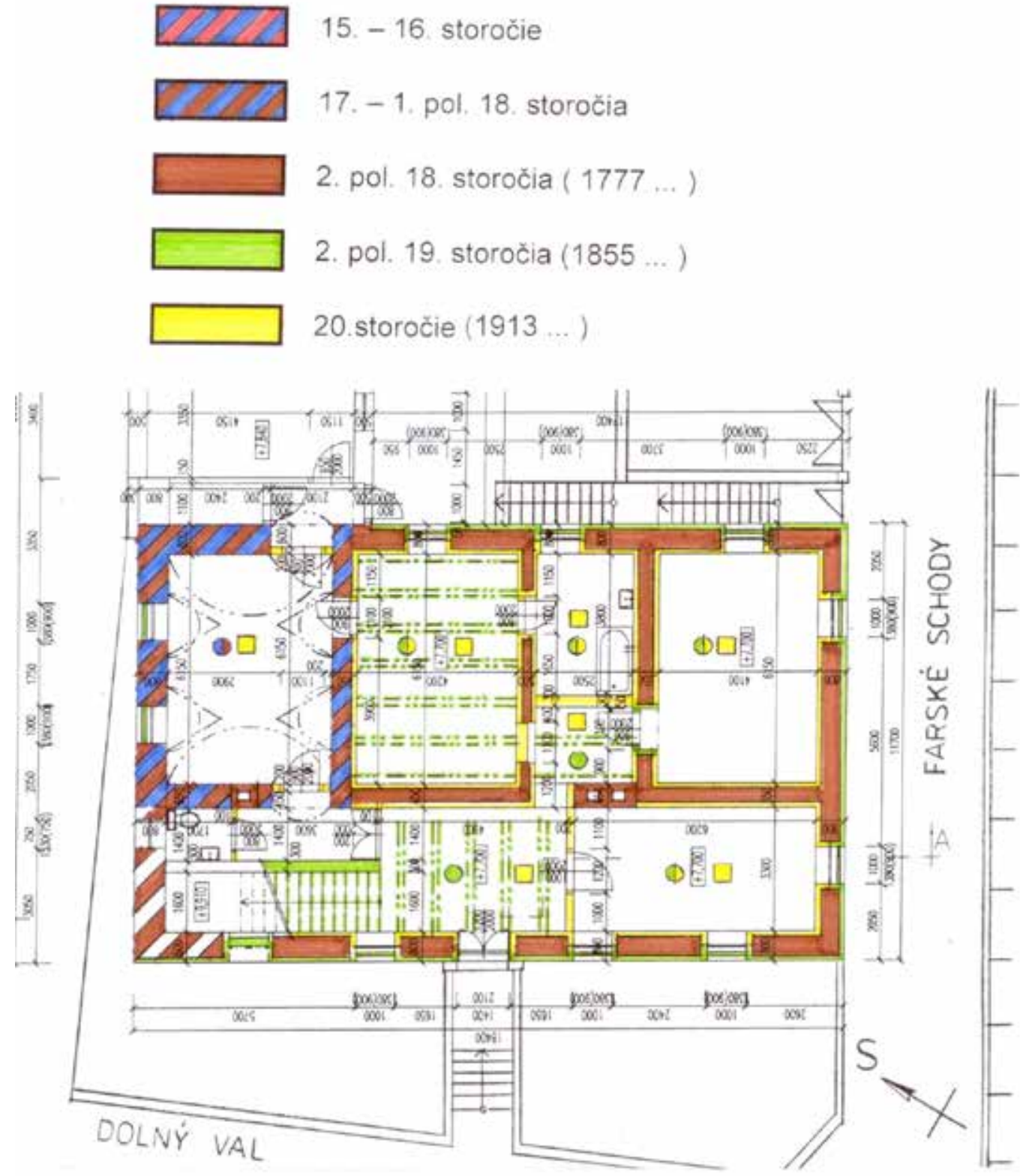

Fig. 8: The construction development of the Rectory according to the architectural-historical study -ground floor plan (Regional Monuments Board of Zilina) 


\section{STAVEBNÝ VÝVOJ}

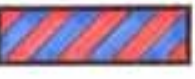

15. - 16. storočie

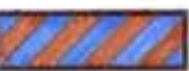

17. - 1. pol. 18. storočia

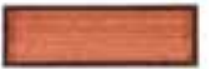

2. pol. 18. storočia $(1777 \ldots)$

2. pol. 19. storočia $(1855 \ldots)$

20. storočie $(1913 \ldots)$

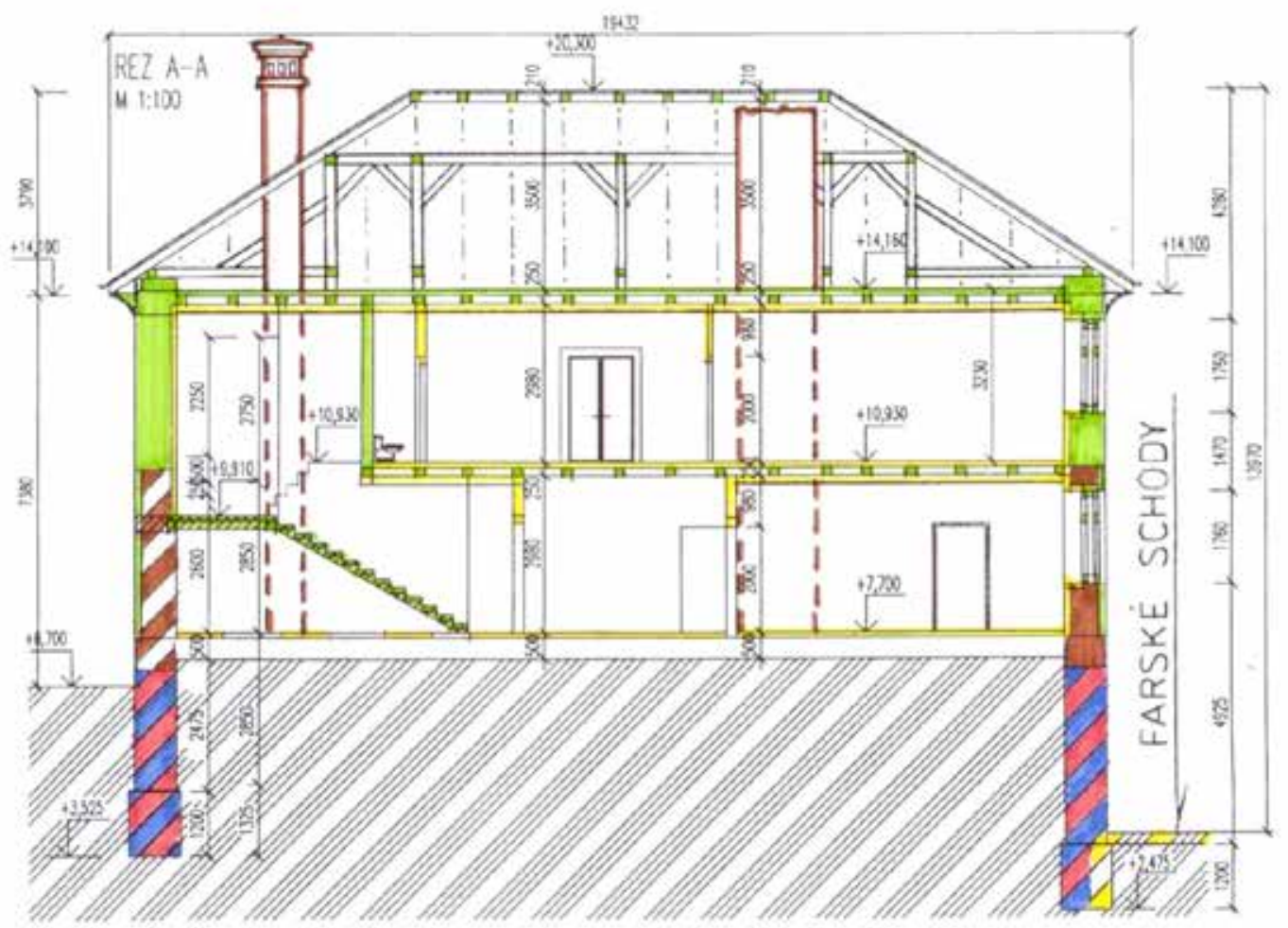

Fig. 9: The construction development of the Rectory according to the architectural-historical study - cross section (Regional Monuments Board of Žilina) 

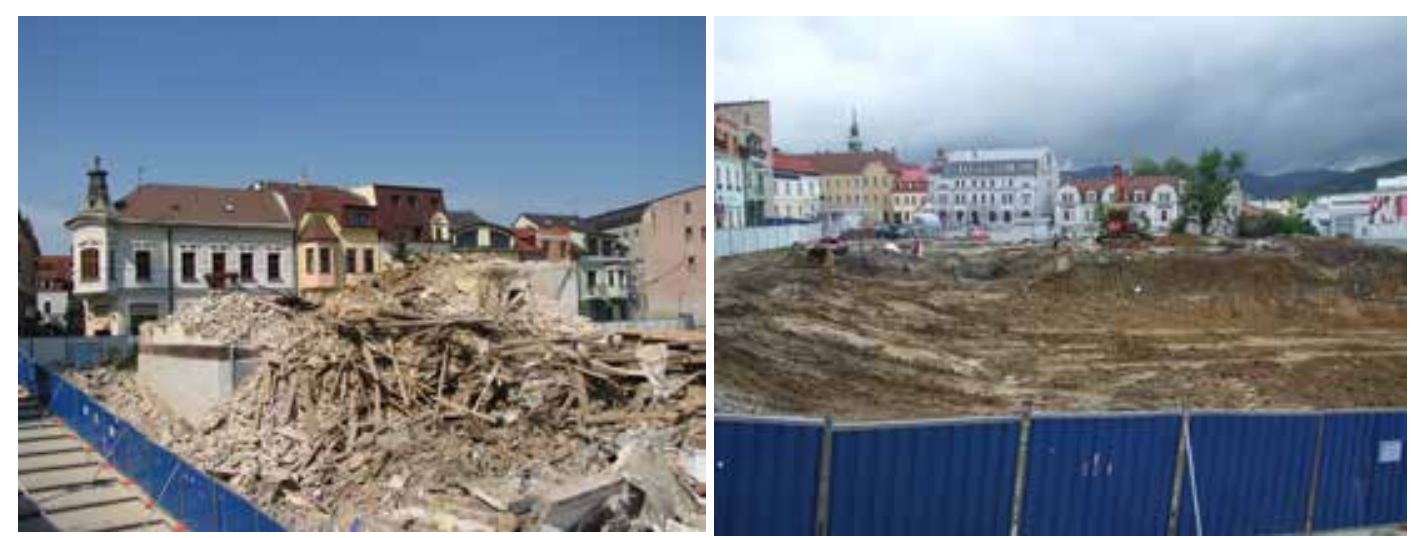

Fig. 10: The remains of the Rectory on Sunday morning, Fig. 11: The Rectory plot one week after demolition (photo: July 13, 2008 (photo: J. Feiler, 2008)

M. Dudás $)$

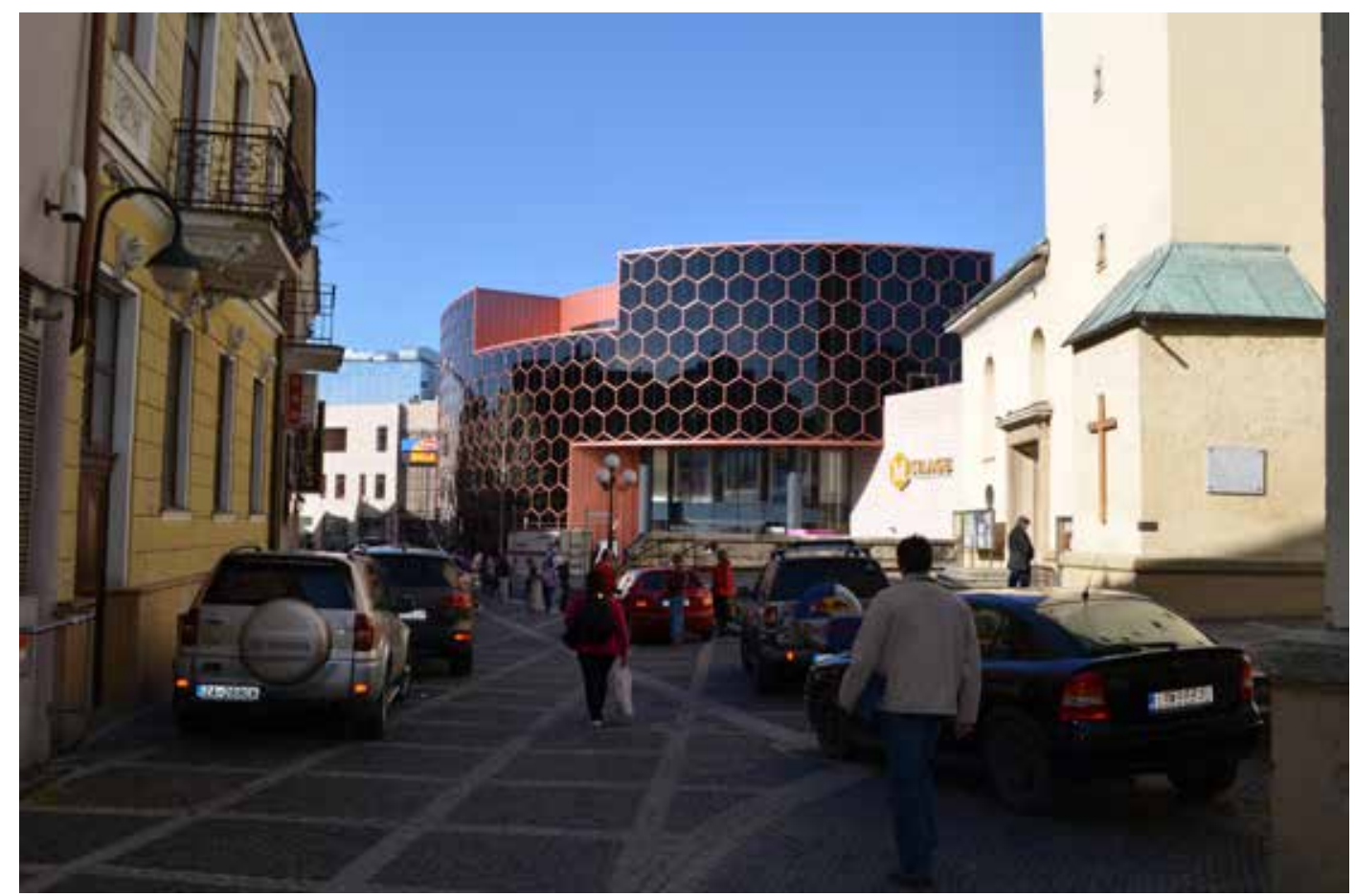

Fig. 12: New shopping centre on the site of the former Rectory (photo: M. Dudás) 